Vol. XVI, No. 4

\title{
New Provincial Plant Records
}

By Keith Best and Archie Budd, Swift Current

During September we ran across two plants hitherto unreported from Saskatchewan, one of which seems to be its first appearance in Canada. East of Maple Creek we found a large patch of Swainsonia or Austrian Wild Pea (Swainsonia salsula (Pall.) Taubert) on the margin of a slough. These were perennial legumes growing about two feet high with pinnately compound leaves with about 19 leaflets. These were wedge-shaped, up to half an inch long and slightly indented at the tip. The pea-like flowers were about $3 / 8$ inch long and brick red in colour, the same colour as scarlet mallow, but dried to a purple tint. The fruiting pods were red when young but the mature pods were pale green, about $3 / 4$ inch long and $1 / 2$ inch wide, much inflated and of a papery texture with a groove along one side. The two rows of seeds were attached on the inside of the groove. A point which assisted in the identification was that the pods were stipitate, with a sitalk attaching them to the remains of the calyx. Swainsonia has been found, but narely, in Arizona, Colorado, Wy-

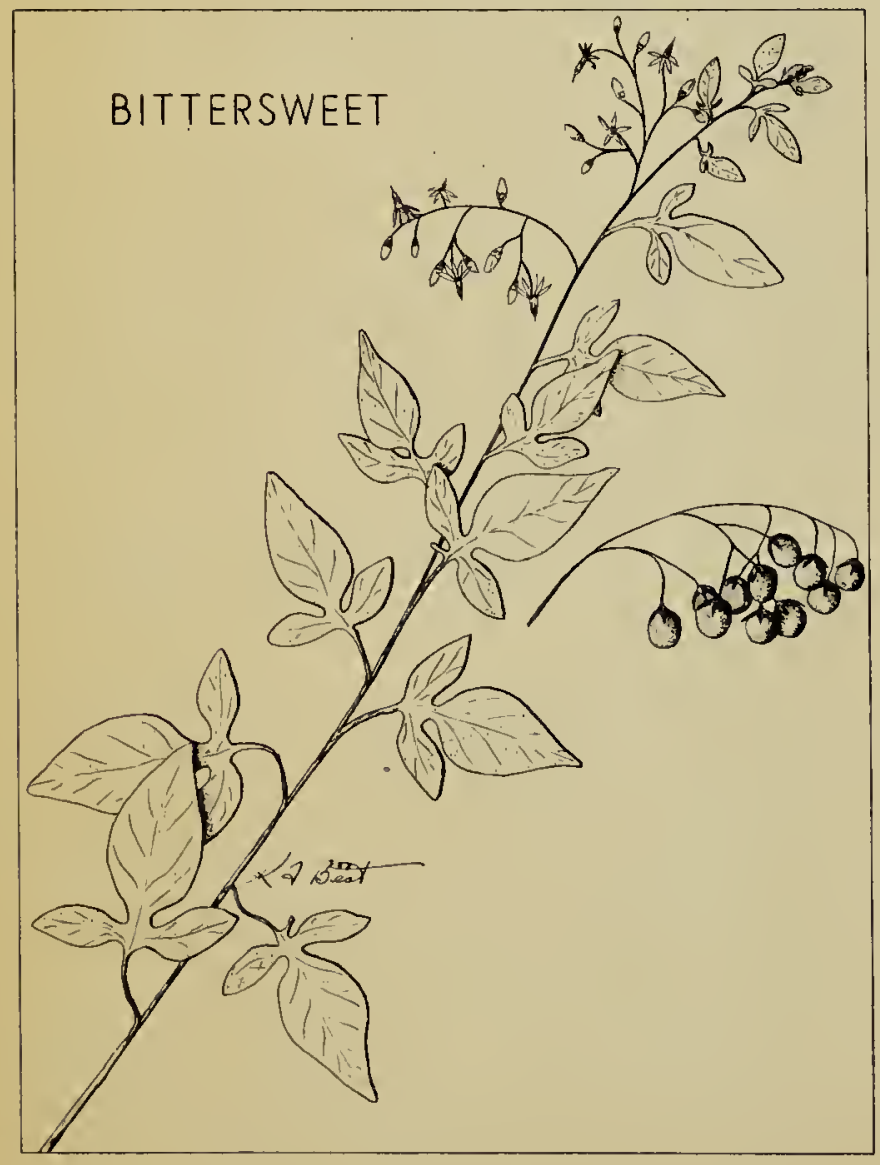

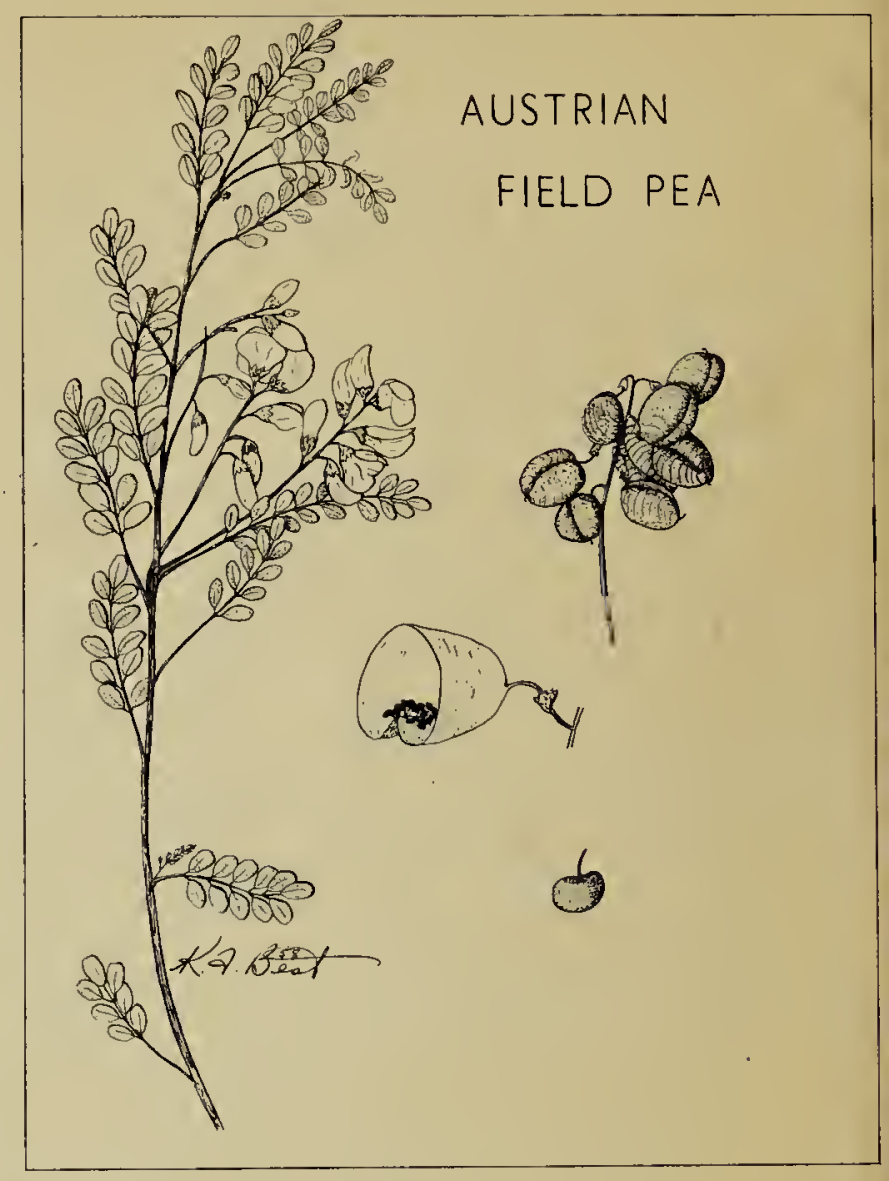

oming and Washington, but originates in Eurasia. Shrubby members of this genus are native to Australia and are used as garden ornamentals in Britain. This appears to be the first Clanadian record. The patch we found was probably from seed brought in from the U.S.A. by an oil explcration rig which had drilled in the immediate vicinity a few years previously.

In the town of Eastend we found considerable European Bittersweet, or Woody Nighitshade, (Solanum Dulcamara L.) the fruit of which is decidedly poisonous. This had apparently been introduced from Wisconsin as an ornamental under the name of Climbing Honeysuckle, but was spreading considerably. This woody based climber bears cordate based oval leaves with pointed tips, sometimes three lobed with small basal lobes. The flowers are deep purple like small potato flowers and the fruits are red, oval berries about $3 / 8$ inch long and quite attractive. Although previously found at Morden, Manitoba, and Edmonton, Alberta, this seems to be the first occurrence in Saskatchewan. 